\title{
Impediments of Students' English Language Speaking Skill in Two Selected Preparatory Schools in Wolaita Zone
}

\author{
Endale Endrias Arega, (MA in TEFL) \\ English Language and Literature Department, \\ Wolaita Sodo University, Ethiopia
}

doi: 10.19044/esj.2017.v13n14p83 URL:http://dx.doi.org/10.19044/esj.2017.v13n14p83

\begin{abstract}
This study was intended to investigate impediments of students' English Language speaking with particular reference to Wolaita Sodo and Areka Preparatory Schools. The study also examines causes that account for these impediments. The subjects of the study were grade 11 students of the aforementioned schools. The samples of the study were 620 students out of 2,388 students in both preparatory schools; again 14 students and 8 English Language teachers were selected for the interview. The sample students were selected using simple random sampling technique. The data gathering instruments used were questionnaire, interview and classroom observation. To achieve the objectives, descriptive method of research design is used. To analyze the obtained data, both qualitative and quantitative methods of data analysis were used. The findings show that: lack of confidence from the student side, excessive use of mother tongue, preference of grammar and vocabulary than speaking, poor speaking background, shortage of vocabulary, teachers' emphasis on grammar and vocabulary, teacher centered way of teaching, large class size, lack of access to teaching aids, shortage of text books and references. Each of these factors was also caused by different problems such as: Classmates' laughing when one makes a mistake while speaking; focusing on teaching grammar than speaking; focusing of exam questions mainly on grammar and vocabulary than speaking, nature of the English Text Book and teachers' experience of traditional teaching. Finally, the recommendations were forwarded based on the findings.
\end{abstract}

Keywords: English Language speaking, impediments, language use, fear, interaction 


\section{Introduction}

It is observable that English has become the medium of international communication, politics, business, diplomacy, education, and technology in the current world. The need to use this language has increased through time in different affairs. In educational affairs, as English is the language that is used for teaching-learning purpose, practical usage of the language has become a key element. Aungwatanakun, (1994) states that in foreign language teaching and learning, ability to speak is the most essential skill since it is the basic for communication. Students' ability to communicate in English is a basic thing that is expected in language learning. Having spoken language proficiency is an indication of being a competent learner. In support of this, Ur (1998) stated that mastery of this skill illustrates that the speaker possesses precise knowledge of language. Again, another scholar Richards (2008) states that learners often evaluate their success in language learning as well as the effectiveness of their English course on the basis of how much they feel they have improved in their English proficiency.

In English classroom, teachers and students use English for various practical purposes in and/or outside the classroom. However, there are various problems that hamper students' speaking of English Language. Therefore, this study is designed to explore hindrances of students' English Language speaking skills in two selected preparatory schools in Wolaita Zone, Ethiopia.

The students' speaking skill of English in discussion, questions, giving responses is very low in English speaking classroom in Wolaita Sodo and Areka Preparatory School. As Sisay, (1999), states if we take a thorough look at the practice in the teaching of speaking skill in English that is going on in Ethiopia high schools today, we may observe multi faceted and deeprooted problems such as focusing on the grammatical aspects of language and inability to communicate orally. Middleton (2009) also argues that most English students are afraid to try and to speak in a foreign language they learn. In this context, as he adds, students do not want to look foolish in front of the class. In some other cases, they also worry about how they will sound, and are scared of sounding silly and so on.

Due to deficiency in using English, the students in Wolaita Sodo and Areka Preparatory Schools encounter different challenges in their learning. Most of the students do not exchange their ideas in English in the classroom. They do not ask when they do have questions and doubts. Since teachinglearning process is a two way practice, if students do not ask their teachers what is not clear for them and do not share their ideas between themselves, we can say that the teaching-learning process of this skill is not at all successful as it is expected to be. 
Majorities of the students use their mother tongue language or keep quite during pair and group discussions; while a teacher tries to move around and observe while the students are discussing/exchanging their ideas using the target language, students pretend that they are using the target language; in fact they are not using it. In short, students are not seen discussing, responding and asking questions using English.

In general, students' poor speaking skill obviously affects the students' learning in different ways. It affects the interaction between student to student, student to teacher and student to school community and people outside the school. It hinders not to share their ideas, feelings and questions. This limitation adversely affects not only students' English speaking at this class level but also learning of other subjects and the future of the students.

\section{Objectives of the Study}

\section{General Objectives of the Study}

The general objectives of this study are:

to assess the current practices of teaching speaking in Wolaita Sodo and Areka Preparatory Schools.

$>\quad$ to investigate the major impediments of students speaking of English Language.

\section{Specific Objectives of the Study}

Founded on the general objectives, the specific objectives of this study are:

$\checkmark \quad$ to investigate teaching method related factors that impede students' English use and their causes.

$\checkmark \quad$ to investigate learner related factors that hamper students' English use and their causes.

$\checkmark \quad$ to investigate teacher related factors that impede students' English use and their causes.

$\checkmark \quad$ to investigate teaching-learning environment and class size related factors that adversely affect students' English Language speaking and their causes.

$\checkmark \quad$ to investigate instructional material related factors that impede students’ English Language speaking and their causes.

\section{Methodology}

For this study, descriptive research design was used. This is because as Kothari (2004) states,

The major purpose of descriptive research is description of the state of affairs as it exists at present. To clearly express the ideas and feelings of 
people, to show the situations and conditions as they currently exist, this method is more convenient.

\section{Sampling Techniques and Sample of the Study}

The subjects of this study were grade 11 students at Wolaita Soddo and Areka Preparatory Schools. The sample size of the study was 620 students out of 2,388 students from both Preparatory Schools. The sample students were selected using simple random sampling technique. The sample students were selected using simple random sampling. Totally, 620 students for the questionnaire, 14 students and 8 English Language teachers were selected for the interview.

\section{Data Collection Instruments}

The researcher used three data gathering tools: questionnaire, interview and observation. The questionnaire was designed as a main instrument of data gathering tool from students. The researcher also used interview and classroom observation to collect data from teachers and students. The questionnaire and interview were translated from English to Wolaittatto and Amharic in order to help students choose the language they understand better so that they may give genuine responses.

\section{Methods of Data Analysis}

Both qualitative and quantitative methods of data analysis were used in this study. In conformity with this, Flick (2002) stated that quantitative and qualitative methods should be viewed as complementary rather than as rival camps. Suitably, tabulation methods, percentage value and frequency counts/distributions was used to analyze the items of questionnaire. And the data that was obtained through interview and classroom observation was described qualitatively.

\section{Results and Discussions}

Table 1. Students' questionnaire responses for student related factors hindering them from using English during English speaking classroom

\begin{tabular}{|c|c|c|c|c|c|c|}
\hline \multirow{2}{*}{ No } & Items & SA & Ag & Un & Ds & SD \\
\cline { 3 - 6 } & & $\mathrm{f}$ & $\mathrm{f}$ & $\mathrm{f}$ & $\mathrm{f}$ & $\mathrm{f}$ \\
& & $\%$ & $\%$ & $\%$ & $\%$ & $\%$ \\
\hline 1.1 & $\begin{array}{c}\text { I have the confidence to speak English freely in } \\
\text { the class without fear of making mistakes and } \\
\text { criticism of friends. }\end{array}$ & 44 & 160 & 110 & 240 & 66 \\
& 7.1 & 25.8 & 17.7 & 38.7 & 10.6 \\
\hline 1.2 & & & & & \\
\hline 1.3 & $\begin{array}{c}\text { I prefer to learn grammar and vocabulary than } \\
\text { speaking English }\end{array}$ & 200 & 228 & 82 & 65 & 45 \\
& I prefer teacher's explanation than practicing \\
speaking activities by myself & 32.3 & 36.8 & 13.2 & 10.5 & 7.3 \\
\hline
\end{tabular}




\begin{tabular}{|c|c|c|c|c|c|c|}
\hline 1.4 & I like to participate in speaking activities (e.g. & 300 & 70 & 172 & 48 & 30 \\
& presentation, group or pair work) using English. & 48.4 & 11.3 & 27.7 & 7.7 & 4.8 \\
\hline 1.5 & I have poor English speaking background. & 180 & 180 & 66 & 100 & 94 \\
& Most of the time I use my mother tongue when I & 29 & 29 & 10.6 & 16.1 & 15.2 \\
\hline 1.6 & $\begin{array}{c}\text { am asked to do activities in pairs (groups) in } \\
\text { English class. }\end{array}$ & 36.9 & 27.4 & 11 & 12.6 & 12.1 \\
& & & & & \\
\hline 1.7 & My mother tongue language pronunciation & 110 & 164 & 100 & 108 & 138 \\
& interferences use of English. & 17.7 & 26.5 & 16.1 & 17.4 & 22.3 \\
\hline 1.8 & I have adequate vocabulary (words) to express my & 80 & 101 & 199 & 104 & 136 \\
& ideas or opinions in English & 12.9 & 16.3 & 32.1 & 16.8 & 21.9 \\
\hline 1.9 & I like practicing speaking in English in and & 300 & 143 & 100 & 70 & 77 \\
& outside the classroom. & 48.4 & 23.1 & 16.1 & 11.3 & 12.4 \\
\hline 1.10 & I like to talk/interact in English with my class & 112 & 122 & 78 & 202 & 106 \\
& friends & 18.1 & 19.7 & 12.6 & 32.6 & 17.1 \\
\hline 1.11 & I like to talk/interact in English with my teacher & 96 & 168 & 128 & 138 & 90 \\
& I have a positive attitude towards English & 284 & 202 & 68 & 36 & 30 \\
\hline 1.12 & Language & 45.8 & 32.6 & 11 & 5.8 & 4.8 \\
\hline
\end{tabular}

$f=$ frequency $\%=$ ercentage SA: Strongly Agree $=5$ Ag: Agree $=4$ Un: Uncertain=3 DS: Disagree=2 SD: Strongly Disagree $=1$

In the above table 1 , item 1.1 it clearly shows that (49.3\%) responded that they are not confident enough to speak English freely in the class without fear of making mistakes and criticism of their class friends. A scholar called Al-Hosni (2014) identifies factors causing speaking difficulties as:

Students are worried about making mistakes fearful of criticism, or simply shy. Students have no motivation to express themselves... only one participant can talk at a time because of large classes and the tendency of some learners to dominate while others speak very little or not at all... learners who share the same mother tongue tend to use it because it is easier and because they feel less exposed if they speak their mother tongue (Hosni, 2014: 123).

Teachers also believe that their learners do not have confidence to speak in English freely in the classroom without being afraid of making mistakes. As the teachers' and students' interview confirm, the cause for students' fear is that they make mistake when speaking and their class friends may laugh and mock at their mistakes. Therefore, the students prefer to keep silent, or they use their mother tongue. In support of this, Mwamba (2005) found out that many students in secondary schools were shy and preferred remaining quiet in class because they were unable to express themselves properly in spoken English.

In table 1 , item 1.2, majority of the respondents $69.1 \%$ replied that they prefer to learn grammar and vocabulary than speaking. As students' 
interview proves, the reason for this is the tests and examinations mainly focus on grammar and vocabulary questions, and their teachers do not give them any speaking activities or tests because they do have shortage of time. In the next item (item 1.3) 80.6\% of the total sample students responded that they prefer teacher's explanation than practicing speaking activities by themselves. As we know, nothing can teach students the speaking skill better than practicing the language by their own. In the next item, $59.7 \%$ of the respondents said that they like to participate in speaking activities (e.g. presentation, group or pair work) using English. The interview and classroom observation results also assure that students were not found participating in the speaking activities.

In the next item 1.5, most of the students 58\% acted in their response that they do have poor English speaking background. The students' interview result evidently shows that the cause for having poor speaking background is the primary school teachers' traditional way of teaching. They did not emphasize teaching the speaking skill. According to the interview result, speaking is one of the skills ignored by the teachers.

Again in item 1.6, 64.3\% of the respondents indicated that most of the time, they use their mother tongue Wolaittatto or Amharic when they are asked to do activities in pairs (groups) in English speaking class. Their interview responses indicated that the reason for this is that they were not used to interact in English before this level, and teachers simply gave group works, but they do not follow up whether the students use the target language or not. In item 1.7, $44.2 \%$ of the respondents reacted that their mother tongue pronunciation interference affects their English; as a result, they don't use the language. Alharbi (2015) states that there are several factors that influence learning of speaking skills; for instance use of mother tongue outside and inside classroom environment... This means that students do have anxiety to speak English because when they speak, they think that they may pronounce as if they speak their mother tongue language.

Regarding item 1.8, which asks if students do have adequate vocabulary to express their ideas or opinions in English, 38.7\% responded that they do not have adequate vocabulary to express their ideas and opinions in English. In the interview, the respondents indicated that, though the students know what to say, they cannot say it due to lack of basic vocabularies.

Students prefer to use English with teachers than students. This is depicted in item 1.10 that $49.7 \%$ of the students responded that they do not like to use English with their class friends, but in item 1.11, 42.6\% responded that they like to talk/interact in English with their teachers. From this, we can state that students prefer to use English with their teachers than their class friends. As the interview clearly shows, this is mainly because 
their classmates laugh/mock if they make mistakes while talking, especially outside the classroom. Finally, in item 1.12, 78.4\% of the students responded that they have a positive attitude towards the English Language. In their interview, it is explained that they are interested to know the language, but due to challenges from their class friends and their past poor experience of speaking English, they fail to use it at this level.

Table 2. Students' questionnaire responses of teacher related factors that impede them from using English during English speaking classroom

\begin{tabular}{|c|c|c|c|c|c|c|}
\hline \multirow{3}{*}{ No } & \multirow{3}{*}{ Items } & SA & $\mathrm{Ag}$ & Un & Ds & SD \\
\hline & & $\mathrm{f}$ & $\mathrm{F}$ & $\mathrm{F}$ & $\mathrm{F}$ & $\mathrm{f}$ \\
\hline & & $\%$ & $\%$ & $\%$ & $\%$ & $\%$ \\
\hline \multirow[t]{2}{*}{2.1.} & My English teacher often emphas & 147 & 149 & 140 & 99 & 85 \\
\hline & than speaking. & 23.7 & 24 & 22.6 & 16.0 & 13.7 \\
\hline \multirow[t]{2}{*}{2.2.} & My English teacher often prefers to explain and & 160 & 170 & 106 & 94 & 90 \\
\hline & $\begin{array}{l}\text { demonstrate than to create condition for the } \\
\text { students to practice speaking. }\end{array}$ & 25.8 & 27.4 & 17.1 & 15.2 & 14.5 \\
\hline \multirow[t]{2}{*}{2.3.} & My English teacher often prefers teacher-centered & 205 & 264 & 82 & 100 & 75 \\
\hline & $\begin{array}{c}\text { way of teaching than student centered in English } \\
\text { speaking class. }\end{array}$ & 33.1 & 42.6 & 13.2 & 16.1 & 12.1 \\
\hline \multirow[t]{2}{*}{2.4.} & Our English teacher encourages & 250 & 169 & 78 & 75 & 48 \\
\hline & language in and outside & 40.3 & 27.3 & 12.6 & 12.1 & 7.7 \\
\hline \multirow[t]{2}{*}{2.5.} & My English teacher provides us with the & 75 & 130 & 100 & 205 & 210 \\
\hline & $\begin{array}{l}\text { opportunity to practice speaking in pairs and } \\
\text { groups in class }\end{array}$ & 12.1 & 21.0 & 16.1 & 33.1 & 33.9 \\
\hline \multirow[t]{2}{*}{2.6.} & My English teacher is proficient enough in & 200 & 200 & 147 & 50 & 113 \\
\hline & English to help us as needed. & 32.3 & 32.3 & 23.7 & 8.1 & 18.2 \\
\hline \multirow[t]{2}{*}{2.7.} & My English teacher provides us activities that & 50 & 132 & 90 & 162 & 186 \\
\hline & promote our speaking skills i & 8.1 & 21.3 & 14.5 & 26.1 & 30.0 \\
\hline \multirow[t]{2}{*}{2.8.} & My English teacher uses teaching aids and & 122 & 89 & 100 & 210 & 99 \\
\hline & $\begin{array}{l}\text { authentic materials in the classroom to promote } \\
\text { our speaking skills }\end{array}$ & 19.7 & 14.4 & 16.1 & 33.9 & 16.0 \\
\hline \multirow[t]{2}{*}{2.9.} & My English teacher usually corrects our errors & 242 & 200 & 90 & 55 & 33 \\
\hline & & 39.0 & 32.3 & 14.5 & 8.9 & 5.3 \\
\hline \multirow[t]{2}{*}{2.10} & My English teacher usually evaluates our & 165 & 160 & 100 & 122 & 73 \\
\hline & $\begin{array}{l}\text { speaking performance through objective } \\
\text { questions: like multiple choice than oral } \\
\text { presentation }\end{array}$ & 26.6 & 25.8 & 16.1 & 19.7 & 11.8 \\
\hline
\end{tabular}

$f=$ frequency $\%=$ percentage $S A=$ Strongly Agree $=5 \quad$ Ag=Agree $=4$ Un=Uncertain=3 $D S=$ Disagree $=2 S D=$ Strongly disagree $=1$

As it can be seen in table 2, item 2.1, 47.7\% of the students responded that their English teachers often emphasize grammar than speaking. According to students' interview, teachers go for only grammar and vocabulary because there is shortage of time, and the English text for grade 11 is too bulky to complete in a given academic year. In the next item (item 2.2), 53.2\% of the respondents indicated that their English teachers often prefer to explain and demonstrate than to create conditions for them to 
practice speaking. In support of this, one of the interviewee said that "Teachers never give us different situation and do not make us stand up and practice speaking English Language. The same student added that teachers simply rush to cover the content of the text book."

In item number $2.3,75.7 \%$ of the sample respondents, showed that their English teachers often prefer teacher-centered way of teaching than student centered way of teaching in English speaking class. Teachers' interview expressed that this is mainly because there is serious shortage of time (42 minutes) to complete a lesson. As can be seen in table 2 item 2.5, majority of the respondents, 67\% agree that their English teachers do not use active learning methods to make students use English in pairs and groups in classroom. One of the teacher interviewees said "Students are not willing enough to use the target language though teachers give them pair and group works; students simply pretend that they use it." Another interviewee elaborated that "Within 42 minutes, it is impossible to make 62 students practice turn by turn; the time is too short to do that." Another interviewee said "Our teacher does not push us to interact in English because he thinks that it is not our mother tongue and we are not good at it; he himself makes use of mother tongue for almost half a period." Teachers in their interview state that their students are not ready for pair and group works in the English classes, rather they like to listen to their teachers only. When students work in pairs and groups, they do not think they are learning English.

For item 2.7, 56.1\% of the students responded that their English teachers do not provide activities that promote their speaking skill in the class. With regard to the usage of teaching aids, in item 2.8, 49.9\% of the sample students responded that their English teachers do not use teaching aids and authentic materials in the classroom to promote their students speaking skill. Again in item 2.9, 71.3\% of the students responded that their English teachers usually correct their errors while they are speaking.

For the last item 2.10, 52.4\% of the students responded that their English teachers usually evaluate their speaking performance through objective questions: like multiple choices than oral presentation. According to the teachers' interview, the reason for this is that most of the students are not willing, and then perform below the standard they are expected. Thus, students can get a better result if they are given an objective test than a practical one.

\section{Interview responses on instructional material}

As it was indicated by the interview, the respondents pointed out that there is shortage of English textbooks in both schools. As one of the teacher said "One textbook is given to two or three students in a section; this has its own effect on students learning." Again another teacher who is older than all 
the interviewees explained "The library has no up to date reference materials that can help students' use of English; the textbook itself is very bulky, so that teachers are tempted whether to cover the book or to teach important portions of the text book." The interview also exposed that the teachers do not use teaching aids that promote the use of English Language. One of the interviewees said "we do not have equipments like tape recorders, cassettes, radio programs and other materials; thus, we cannot use teaching aids in English speaking classroom to promote students' practical use of English Language." This means that lack of those materials is seriously affecting the students’ opportunity to use the target language.

\section{Teaching-learning environment and class size}

The interview depicts that the classroom environment and class size related factors are some of the hindrances that affect students' English speaking skill. In the classroom environment, as there are no native speakers of this language, the students do not have any exposure to use English Language. One of the interviewees said that "If I am seen using English outside the classroom, I will be found ridiculous; the environment does not encourage using the language." Again, it is elaborated that the large number of students in each class is the greatest challenge to the teaching of English speaking skill. One of the interview respondents said "Having large number of students in a class is an obstacle for making students speak turn by turn; it is unsuitable even to control." The interviewee continued "If the students' number is smaller, it would not be challenging to make students use the target language.

\section{Classroom Observation Results}

During the observation sessions, the total of fifteen sessions were observed in five sections (three different sessions in each section) to triangulate what actually was happening in practical classrooms with the information obtained through the questionnaire and interview. The classroom observation results are discussed below.

In the fifteen observation sessions, the following results are found. The classroom observation shows that the speaking classroom activities do not promote the use of language. Again, the speaking activities do not encourage students to interact with each other in pairs/groups. As students mentioned in their interview, the reason for this is that the activities are not convenient for dialogue. Most of the activities, instruct rather than giving the tasks in a dialogue form.

According to the classroom observation, when they teach speaking lesson, the teachers do not carry out the activities like role play, games, simulation etc. In support of this, (Alharbi 2015:109) states that: 
Pair work, group work, role playing and interviews ... encourage shy students to participate and discuss their opinions with their classmates instead of only with teachers. Employing various techniques in the classroom also challenges students and caters for diversity in students' learning styles.

Teachers do not give time for oral practice activities. As the observation confirms, almost no time is given to oral practice. In the same way as students' interview and questionnaire indicate, the classroom observation also shows that the teachers prefer to explain and demonstrate than to provide activities for the learners.

The observation sessions indicated that the teachers do not encourage their students to participate in group or pair works. Let alone the encouragement, the teachers did not group their students throughout the observed sessions. The teachers do not use teaching aids like tape recorder, cassettes, and other authentic materials in the class, and they use teacher centered method of teaching.

Regarding the assessment of students overall behavior during the classroom observation in speaking lesson, students do not have the confidence to speak freely in class. The students were not using the target language in the classroom even when the teachers asked. Most of the teachers didn't give pair/group works to their students to make their students use English. Students were using their mother tongue. Again it was observed that students seemed to have inadequate vocabulary. As a result, students only attempted to answer individual short oral questions. Finally, it was clearly observed that the number of students in each class was very large. The average number of students in a class was 62 . There was also shortage of seats. Three or four students seated on a desk. Moreover, the seats were not easily movable to organize groups.

\section{Conclusions and Recommendations Conclusion}

Based on the findings, the following conclusions are made: most of the students do not have the confidence to speak English freely in the speaking classroom. This is because the students are afraid of making mistakes. The students prefer to learn grammar and vocabulary than speaking. Also the examinations mostly focus on grammar and vocabulary than speaking. Second, teachers also prefer to teach grammar and vocabulary because there is shortage of time to teach speaking lessons. Most of the students and teachers think that the speaking skill is not as important as grammar and vocabulary. Students do not have speaking background in their lower grades, so that they make frequent use of their mother tongue. Teachers do not give time for students to practice the English language in 
real situations. Currently, most of the high school teachers do have low status of English speaking skills. Use of mother tongue by teachers to explain difficult concepts, teachers' traditional method of teaching, and students' passiveness in the classroom influence students' speaking skill at these schools.

Because the teachers in lower grades do not focus on the speaking skill, the students lack experience to use the target language in and outside the classroom. Their mother tongue language pronunciation also affects their English speaking skill. Besides, teachers do not use English during their course delivery. Instead they use their mother tongue. This is wrong and has a negative consequence on the students' English speaking skill.

English teachers emphasize grammar than speaking because the examinations focus on grammar than speaking. They do not give communicative activities to their students in the classroom. They also skip speaking activities because the English textbook is too bulky to finish in the schedule. Since the teachers' way of giving instruction is teacher centered, the students do not get any opportunity to use the target language in pairs and groups. In the schools, there are no enough references to promote the learners' use of English. The students do not have access to get teaching aids that promote their speaking skill. Moreover, teachers use other local languages inside English Language in the classroom. All the aforementioned problems contributed to students' poor use of English Language in speaking classroom in the selected schools.

\section{Recommendations}

Derived from the results, the following recommendations are forwarded: The greatest responsibility lies on the teachers at all levels of grades to make the students use the target language. Thus, they should construct a variation of English speaking activities which motivate students to learn. English Language teachers at lower grades should know that speaking skill is so important, and its foundation must be laid in lower grades. They should give time for speaking activities that promote students' speaking skill and make the learners practice interacting with one another, and they should use teaching aids and authentic materials in the classroom to promote students' speaking skill. Teachers should play their roles as a provider, an assistant, a consultant to increase effectiveness in the learning environment. Students should strive to use only English during the speaking classroom. They should change the role from passive to active learners. Interaction in the language classroom can decrease students' anxiety in learning English speaking skills. Thus, teachers should focus on communicative activities that actively engage all students. In support of this, Achmal and Yusuf (2014) state in Benter (2015) that: 
In speaking class, teachers are required to create communicative and interactive activities by giving students a great deal of opportunities to practice the target language. Essentially, the class manifests student-centered backdrop rather than teacher centered... teachers are to prepare classroom activities that are devoted and best facilitate speaking exercises.

As students focus on learning grammar and vocabulary, they should also emphasize learning speaking skills. Students should understand that laughing and mocking at their classmates who try to interact in English and make mistakes is inappropriate. They should rather encourage and help their friends who try to use the target language.

English Language teachers should assess their students' English speaking skill like other skills. They should advance student centered way of teaching technique such as: group and pair work, oral presentations etc to involve students actively in the speaking activities.

Schools and other concerned bodies should work on qualifying teachers in lower grade level giving different capacity building trainings. The concerned bodies should make available all the necessary equipments that help in promoting students' speaking skill. Additionally, they should also distribute enough number of student textbooks and get up-to-date English Language speaking reference books that can help the learners improve their speaking skills.

In whatsoever situation they are, the teachers should use only the target language (English Language), so that the students can model and start to use the expressions being used by teachers in the speaking classroom.

\section{References:}

1. Achmad, D. \& Yusuf, Y. Q. (2014). Observing Pair-work in An English Speaking Class. International Journal of Instruction. January 2014, Vol.7 No. 1.

2. Alharbi, A. (2015). Improving Students' English Speaking Proficiency in Saudi Public Schools. International Journal of Instruction Vol. 8, No. 1 Jan 2015.

3. Al Hosni, Samira, (2014). Speaking Difficulties Encountered by Young EFL Learners. International Journal on Studies in English Language and Literature (IJSELL) Volume 2, Issue 6, June 2014, pp. 22-30.

4. Aungwatanakun, S. (1994) English Teaching Methodology, (2nd), Bangkok: Chulalongkorn University Press, 1994.

5. Bahanshal A. D. (2013). The Effect of Large Classes on English Teaching and Learning in Saudi Secondary Schools. English Language Teaching. Vol. 6, No. 11. 
6. Benter, O. (2015). Teaching Speaking Skills in English Language using Classroom Activities in Secondary School Level in Eldoret Municipality, Kenya: Journal of Education and Practice : Vol.6, No.35, 2015

7. Flick, U. (2002) An Introduction to Qualitative Research. SAGE Publications.

8. Kothari, R. (2004). Research Methodology, Methods and Techniques. $\left(2^{\text {nd }}\right.$ ed) New Delhi: New Age International (P) Ltd

9. Middleton, F. (2009). Overcome Your Fear of Speaking Foreign Languages.

[Online] (http://www.eslteachersboard.com/cgibin/language/index.pl?page=2;r ead=1071 (March 17, 2010)

10. Mwamba, R. (2005). An Investigation into Factors that Hinder the Instruction of Oral Communication Skills in English Kenyan Secondary Schools: A case of Kisii district'”. Eldoret Moi University; (Unpublished M.Phil thesis)

11. Richards, J. C. (2008). Teaching Listening and Speaking: From Theory to Practice. Cambridge: Cambridge Press University.

12. Sisay A. (1999). Classroom Interaction and Its Influence on the Development of Students' Speaking Skill. (Unpublished M.A. Thesis) Addis Ababa: AAU.

13. Ur, P. A Course in Language Teaching, Cambridge: Cambridge University Press, 1998. 